\title{
Terrestrial carbon sink observed from space: variation of growth rates and seasonal cycle amplitudes in response to interannual surface temperature variability
}

\author{
O. Schneising, M. Reuter, M. Buchwitz, J. Heymann, H. Bovensmann, and J. P. Burrows \\ Institute of Environmental Physics (IUP), University of Bremen FB1, Bremen, Germany \\ Correspondence to: O. Schneising (oliver.schneising @iup.physik.uni-bremen.de)
}

Received: 1 August 2013 - Published in Atmos. Chem. Phys. Discuss.: 30 August 2013

Revised: 3 December 2013 - Accepted: 4 December 2013 - Published: 3 January 2014

\begin{abstract}
The terrestrial biosphere is currently acting as a net carbon sink on the global scale, exhibiting significant interannual variability in strength. To reliably predict the future strength of the land sink and its role in atmospheric $\mathrm{CO}_{2}$ growth, the underlying biogeochemical processes and their response to a changing climate need to be well understood. In particular, better knowledge of the impact of key climate variables such as temperature or precipitation on the biospheric carbon reservoir is essential.

It is demonstrated using nearly a decade of SCIAMACHY (SCanning Imaging Absorption spectroMeter for Atmospheric CHartographY) nadir measurements that years with higher temperatures during the growing season can be robustly associated with larger growth rates in atmospheric $\mathrm{CO}_{2}$ and smaller seasonal cycle amplitudes for northern midlatitudes. We find linear relationships between warming and $\mathrm{CO}_{2}$ growth as well as seasonal cycle amplitude at the $98 \%$ significance level. This suggests that the terrestrial carbon sink is less efficient at higher temperatures during the analysed time period. Unless the biosphere has the ability to adapt its carbon storage under warming conditions in the longer term, such a temperature response entails the risk of potential future sink saturation via a positive carbon-climate feedback.

Quantitatively, the covariation between the annual $\mathrm{CO}_{2}$ growth rates derived from SCIAMACHY data and warm season surface temperature anomaly amounts to $1.25 \pm$ $0.32 \mathrm{ppm} \mathrm{yr}^{-1} \mathrm{~K}^{-1}$ for the Northern Hemisphere, where the bulk of the terrestrial carbon sink is located. In comparison, this relationship is less pronounced in the Southern Hemisphere. The covariation of the seasonal cycle ampli-
\end{abstract}

tudes retrieved from satellite measurements and temperature anomaly is $-1.30 \pm 0.31 \mathrm{ppm} \mathrm{K}^{-1}$ for the north temperate zone. These estimates are consistent with those from the CarbonTracker data assimilated $\mathrm{CO}_{2}$ data product, indicating that the temperature dependence of the model surface fluxes is realistic.

\section{Introduction}

The atmospheric abundance of the most important anthropogenic greenhouse gas carbon dioxide $\left(\mathrm{CO}_{2}\right)$, which contributes substantially to global climate change, has increased significantly since pre-industrial times as a result of human activities (Climate Change, 2007). Emissions from fossil fuel burning and land use change are estimated to be $F_{\text {fos }}=8.3 \pm 0.4 \mathrm{PgC} \mathrm{yr}^{-1}$ and $F_{\text {luc }}=1.0 \pm 0.5 \mathrm{PgC} \mathrm{yr}^{-1}$, respectively, for the time period 2002-2011, leading to an atmospheric $\mathrm{CO}_{2}$ growth rate of $4.3 \pm 0.1 \mathrm{PgC} \mathrm{yr}^{-1}$, which corresponds to a total $\mathrm{CO}_{2}$ airborne fraction of about $45 \%$. The residual natural net sink is divided into $2.5 \pm 0.5 \mathrm{PgCyr}^{-1}$ being taken up by the oceans and $2.6 \pm 0.8 \mathrm{PgC} \mathrm{yr}^{-1}$ being taken up by the terrestrial ecosystems (Le Quéré et al., 2013). Hence, the terrestrial carbon sink is responsible for removing about one third of total anthropogenic $\mathrm{CO}_{2}$ emissions from the atmosphere and its variability is driven by short-term changes in climate, with less removal occurring during warmer periods (Braswell et al., 1997; Houghton, 2000). This is attributed to metabolic changes in the vegetation, whereby ecosystem respiration responds more sensitively to temperature changes than photosynthesis-induced 
gross primary production (GPP) (Woodwell et al., 1998). Although GPP typically increases with temperature under unstressed conditions, respiration increases proportionately more, yielding reduced net ecosystem exchange (NEE) (Myneni et al., 1995). In particular, a linear relationship between the reduction in tropical land carbon storage and warming has been proposed using an ensemble of models (Cox et al., 2013). In addition, GPP is reduced during thermal or water stress due to stomatal closure to retain water and to prevent the plant from drying out (Ciais et al., 2005).

Previous relevant studies used localised accurate in situ surface measurements of concentrations or fluxes. The interannual variability of boreal carbon uptake derived from global column-averaged dry air mole fractions of atmospheric carbon dioxide (denoted $\mathrm{XCO}_{2}$ ) was first analysed by Schneising et al. (2011) and potentially attributed to temperature differences using the SCIAMACHY (SCanning Imaging Absorption spectroMeter for Atmospheric CHartographY) instrument onboard the European satellite ENVISAT (launched in 2002, end of mission declared in 2012) (Burrows et al., 1995; Bovensmann et al., 1999). First results concerning the connection of seasonal cycle drawdown minima and temperature using $\mathrm{XCO}_{2}$ from the locally sparse but growing Total Carbon Column Observing Network (TCCON) (Wunch et al., 2011a) were reported recently by Wunch et al. (2013). Efforts to incorporate global satellite data from TANSO onboard GOSAT (launched in 2009) (Kuze et al., 2009) were limited to two or four years of data (Guerlet et al., 2013b; Wunch et al., 2013), rendering a robust analysis of the interannual variability of the atmospherebiosphere interaction difficult.

In this manuscript, we present an analysis of variations of growth rates and seasonal cycle amplitudes in response to interannual surface temperature anomaly variability using long-term global satellite observations from SCIAMACHY. In contrast to other satellite instruments, the measurements of SCIAMACHY and more recently TANSO yield atmospheric $\mathrm{CO}_{2}$ with high sensitivity down to the Earth's surface, where the sources and sinks are located. Taking advantage of the availability of almost a decade of global $\mathrm{XCO}_{2}$ retrievals from satellite, it is demonstrated in this study that significant correlations (or anticorrelations) of the annual atmospheric $\mathrm{CO}_{2}$ growth rate and seasonal cycle amplitude with surface temperature anomaly during the growing season are readily identified.

\section{Data set}

We analyse $\mathrm{XCO}_{2}$ retrieved from SCIAMACHY onboard ENVISAT using Weighting Function Modified DOAS (WFM-DOAS) (Buchwitz et al., 2005; Schneising et al., 2008, 2011, 2012; Heymann et al., 2012) for the entire operational lifespan of the satellite. To minimise residual systematic retrieval biases, an additional (post-processing) cor- rection based on multivariate linear regression is applied (Wunch et al., 2011b; Schneising et al., 2013; Guerlet et al., 2013a). More precisely, we analysed correlations of the difference of the WFMD retrievals to the 2011_oi release of the CarbonTracker assimilation system (Peters et al., 2007, http: //carbontracker.noaa.gov) with state vector and parameter vector elements or instrument and atmospheric parameters for the year 2007 at seven observational sites used in CarbonTracker: Niwot Ridge (USA), Southern Great Plains (USA), Mace Head (Ireland), Ochsenkopf (Germany), Lampedusa (Italy), Assekrem (Algeria), and Cape Ferguson (Australia). As these locations span a wide range of retrieval conditions (e.g. low and high albedo or atmospheric water vapour) and the model-data mismatch at these sites is small $(\bar{\Delta}=$ $0.0 \mathrm{ppm}, \sigma_{\Delta}=0.4 \mathrm{ppm}$ ), which means that CarbonTracker is expected to simulate the corresponding surface flask observations well there, it is assumed that the found correlations on this small subset represent systematic retrieval errors existing all over the world and at all times. Hence, the following correction is applied on Level 2 basis for the entire global multiyear data set universally:

$$
\begin{aligned}
\mathrm{XCO}_{2}^{\text {cor }} & =0.9 \cdot \mathrm{XCO}_{2}-36 \mathrm{ppm} \%{ }^{-1} \cdot \mathrm{O}_{2}^{\mathrm{err}}-4 \mathrm{ppm} \cdot I \\
& -1.8 \mathrm{ppm} \cdot \mathrm{H}_{2} \mathrm{O}^{\mathrm{para}}-27 \mathrm{ppm} \cdot \mathrm{O}_{2}^{\mathrm{para}} \\
& -18.5 \mathrm{ppm} \cdot v^{\mathrm{sol}}+1 \mathrm{ppm} \%^{-1} \cdot \mathrm{CO}_{2}^{\text {err }} \\
& -135 \mathrm{ppm} \cdot t+0.17 \mathrm{ppm} \mathrm{cm}{ }^{2} \mathrm{~g}^{-1} \cdot \mathrm{H}_{2} \mathrm{O} \\
& +237 \mathrm{ppm}
\end{aligned}
$$

Thereby, $\mathrm{O}_{2}^{\text {err }}$ and $\mathrm{CO}_{2}^{\text {err }}$ are the retrieved column errors in $\%$ estimated from fit quality and the diagonal elements of the covariance matrix (Schneising et al., 2008), $I$ is the sun-normalised radiance at $1560 \mathrm{~nm}$, and $t$ is the SCIAMACHY nadir throughput at $750 \mathrm{~nm}$ derived by solar measurements. $\mathrm{H}_{2} \mathrm{O}^{\text {para }}$ is the ratio of the radiance at $1.4 \mu \mathrm{m}$ to the clear-sky radiance minus $1, \mathrm{O}_{2}^{\text {para }}$ is the ratio of the retrieved $\mathrm{O}_{2}$ column to the a priori column determined by surface elevation, $v^{\text {sol }}$ is the geometric intra-annual solar variability factor accounting for the variable distance of the Earth to the Sun, and $\mathrm{H}_{2} \mathrm{O}$ is the simultaneously retrieved water vapour vertical column amount in $\mathrm{g} \mathrm{cm}^{-2}$. An additional term $\left(-0.5 \mathrm{ppmpm}^{-1} \cdot f_{\mathrm{a}}\right)$ accounts for a small drift of the instrument slit function before 2004, identified using retrieved slit functions of the Bremen Optimal Estimation DOAS (BESD) $\mathrm{XCO}_{2}$ algorithm (Reuter et al., 2010, 2011), where $f_{\mathrm{a}}$ is the corresponding slit function anomaly in $\mathrm{pm}$. The resulting data set is referred to as WFMDv3.6. The restriction to a single year for derivation of the linear regression parameters ensures that all retrieved interannual variabilities are solely a feature of the satellite data and not artificially introduced as a result of the post-processing correction. Figure 1 shows the spatial distribution of $\mathrm{XCO}_{2}$ for the year 2007 and the observational sites used to derive the linear regression parameters. Figure 2 gives an overview of the longterm global $\mathrm{XCO}_{2}$ data set showing column-averaged dry air 


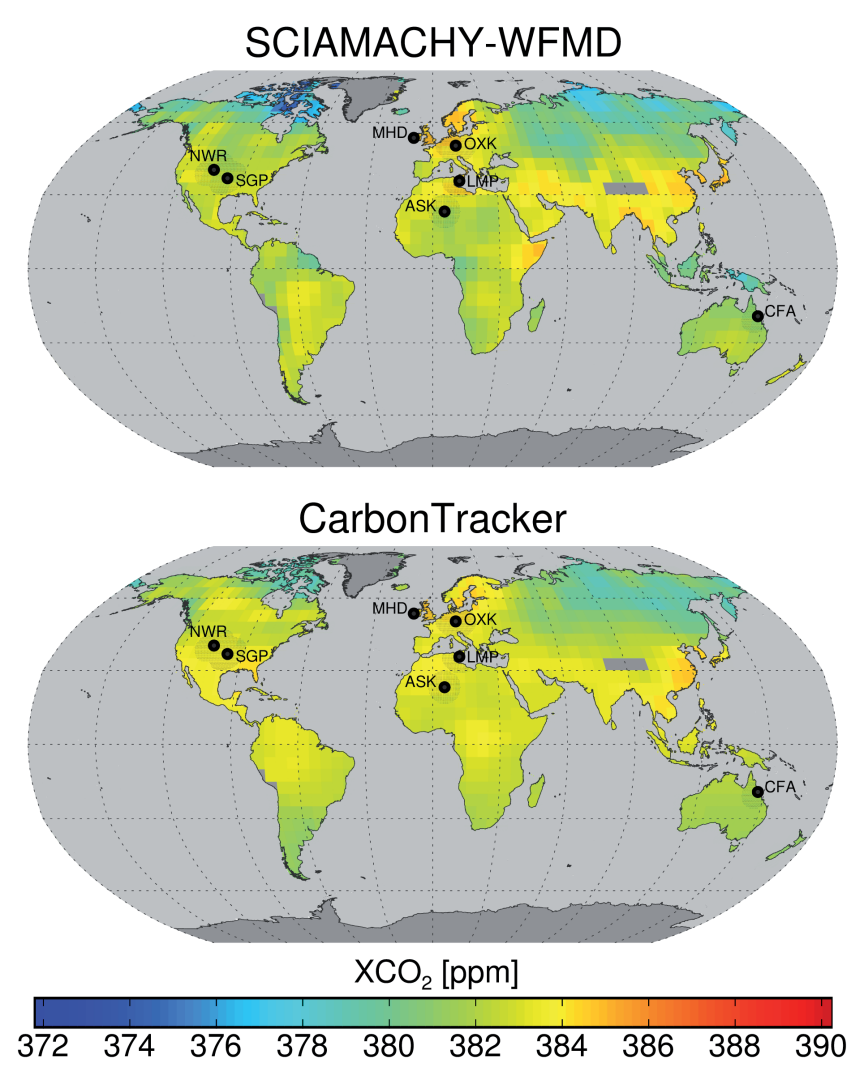

Fig. 1. Spatial distribution of SCIAMACHY and CarbonTracker $\mathrm{XCO}_{2}$ for the year 2007 and the observational site locations used to derive the linear regression parameters: Niwot Ridge (NWR), Southern Great Plains (SGP), Mace Head (MHD), Ochsenkopf (OXK), Lampedusa (LMP), Assekrem (ASK), and Cape Ferguson (CFA). CarbonTracker has been sampled at the time and location of the SCIAMACHY measurements.

mole fractions as a function of latitude and time. In addition to the pronounced seasonal cycle in the Northern Hemisphere due to the temporally varying imbalance between photosynthesis and respiration of vegetation, the steady increase in atmospheric carbon dioxide primarily caused by the burning of fossil fuels is clearly observed.

Based on a comparison with ground-based Fourier transform spectrometer (FTS) measurements of the Total Carbon Column Observing Network (TCCON) and CarbonTracker results at 11 TCCON sites, namely Sodankylä (Finland), Białystok (Poland), Bremen (Germany), Karlsruhe (Germany), Orléans (France), Garmisch (Germany), Park Falls (USA), Lamont (USA), Darwin (Australia), Wollongong (Australia), and Lauder (New Zealand), we conclude consistently that the SCIAMACHY data set is characterised by a relative single measurement precision of about $3.9 \mathrm{ppm}$ and a relative accuracy quantifying regional biases of $1.0 \mathrm{ppm}$ using single measurements within radii of $350 \mathrm{~km}$ around the TCCON sites and the well-established comparison method described in Reuter et al. (2011) and Schneising et al. (2012).

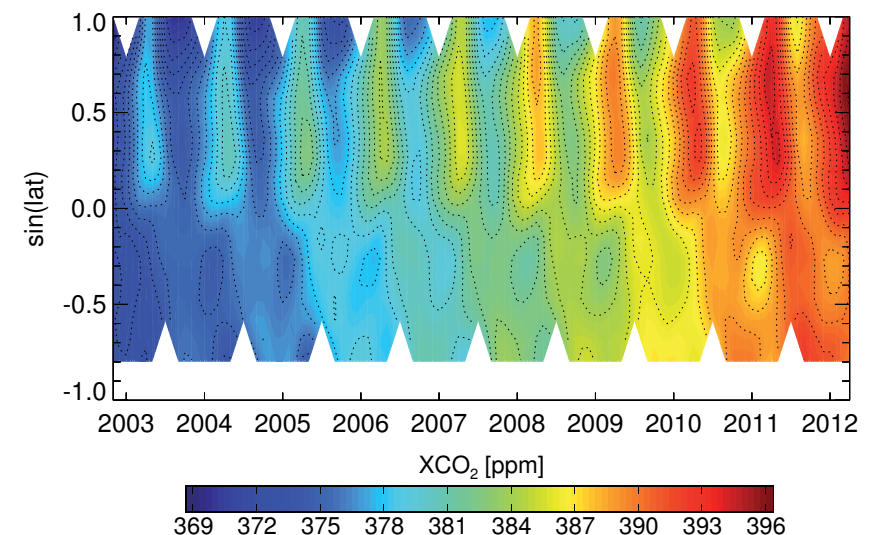

Fig. 2. Overview of the long-term global WFMDv3.6 $\mathrm{XCO}_{2}$ data set; shown are column-averaged dry air mole fractions as a function of latitude and time.

\section{Results}

To examine the interannual variability of the growth rates and seasonal cycle amplitudes, the SCIAMACHY results are compared with CarbonTracker release 2011_oi assimilations (Peters et al., 2007, http://carbontracker.noaa.gov), taking the satellite altitude sensitivity into account. CarbonTracker has been sampled at the time and location of the SCIAMACHY measurements. As can be seen in Figs. 3 and 4, both time series are highly correlated and exhibit consistent growth rates and seasonal cycle phases in both hemispheres. The growth rates are derived by differentiation of the deseasonalised trends, which are obtained by using a 12-month running mean. Hence, the deseasonalised trend is not available for the first and the last six months of the time series, so that the years 2003 and 2011 are not entirely covered. As a consequence, the analysis of growth rates is restricted to the years 2004-2010. The same is true for the seasonal cycle amplitudes obtained from the seasonal cycle maxima and minima of the detrended time series, which are derived by subtracting the deseasonalised trends from the original time series.

\subsection{Atmospheric growth rate}

The mean values of growth rates of SCIAMACHY and CarbonTracker are in very good agreement for both hemispheres. In the Northern Hemisphere the averaged yearly increase amounts to $1.96 \pm 0.05 \mathrm{ppmyr}^{-1}$ for SCIAMACHY and $1.94 \pm 0.05 \mathrm{ppmyr}^{-1}$ for CarbonTracker, whereas the mean growth is consistently a little smaller in the Southern Hemisphere $\left(1.89 \pm 0.05\right.$ and $\left.1.90 \pm 0.03 \mathrm{ppm} \mathrm{yr}^{-1}\right)$. Besides the mean values, also the temporal variability of the SCIAMACHY and CarbonTracker growth rates is in good agreement in both hemispheres.

The variability of the CarbonTracker $\mathrm{XCO}_{2}$ growth rate is directly driven by the total land fluxes, which is reflected in significant correlations at the $99 \%$ or rather $99.95 \%$ 

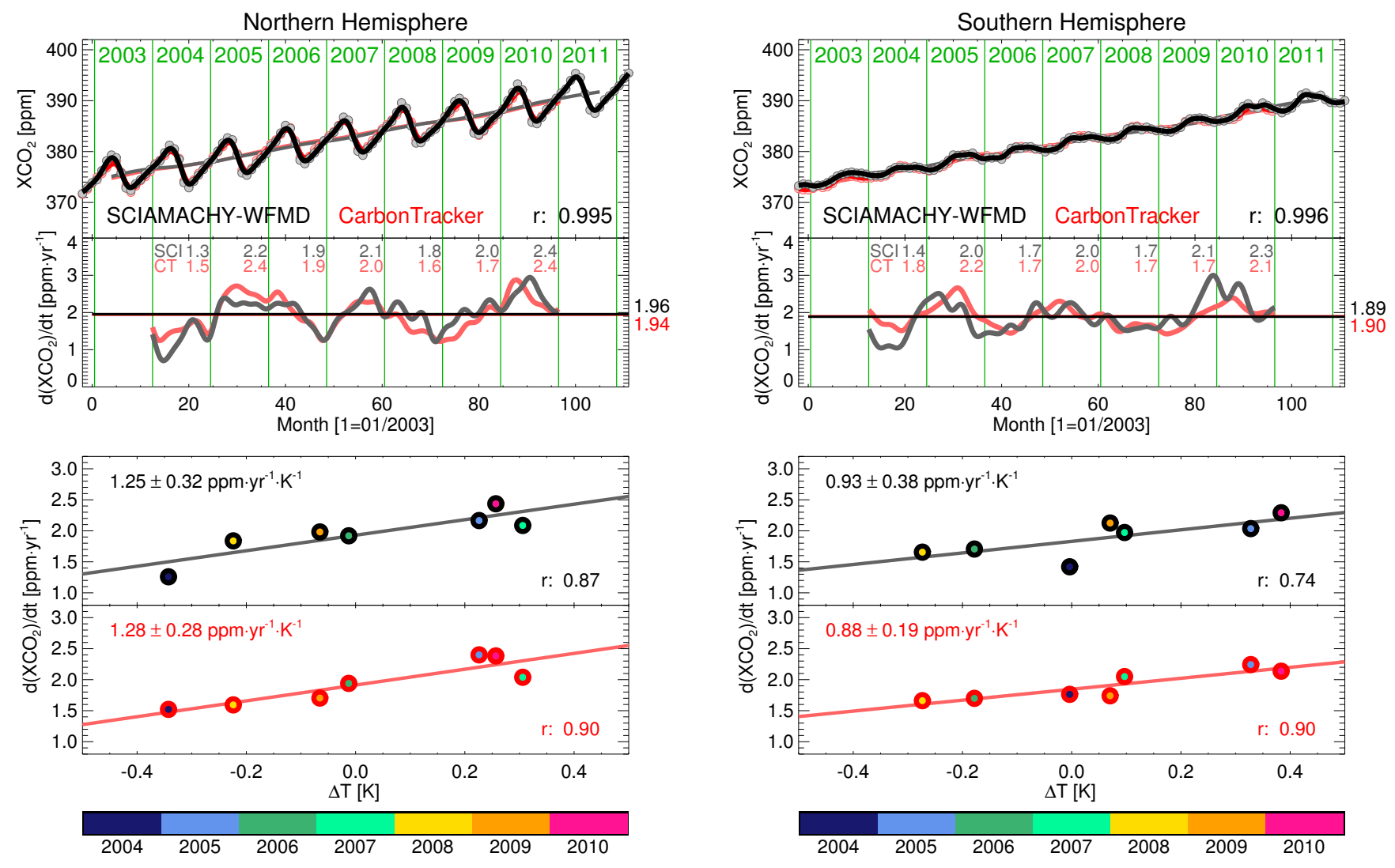

Fig. 3. Comparison of the SCIAMACHY (black) and CarbonTracker (red) $\mathrm{XCO}_{2}$ for the Northern Hemisphere based on monthly means (coloured circles). The saturated solid lines have been smoothed using a four-month Hann window (which has a similar frequency response to a two-month boxcar filter but better attenuation of high frequencies). The pale solid lines represent the corresponding deseasonalised trends derived using a 12-month running mean. Shown below are the derivatives of these deseasonalised curves. Also noted are annual mean values of the growth rate (in pale colours) as well as the mean value of the whole time period on the right-hand side. The bottom panel shows the covariation of annual atmospheric growth rates and the Northern Hemisphere warm season (April-September) surface temperature anomaly.

significance level for both hemispheres. Atmospheric transport only plays a minor role when considering hemispheric means. An analysis of the covariation of CarbonTracker annual land fluxes and atmospheric $\mathrm{XCO}_{2}$ growth rates for the Northern Hemisphere allows quantification of the contributions of the different flux components (biosphere, fossil, and fire emissions) to the interannual variability of the atmospheric growth rates. As a result, biospheric fluxes contribute strongest to the covariation of northern hemispheric total flux and atmospheric $\mathrm{CO}_{2}$ growth rate, while the contributions of the fossil fuel and fire emission signatures are less pronounced, demonstrating that the biospheric fluxes are predominantly driving the variability of the growth rate. The same is true when restricting to fluxes during the growing

Fig. 4. As Fig. 3 but for the Southern Hemisphere and Southern Hemisphere growing season (December-May) surface temperature anomaly.

season, which dominate distinctly the variability of the annual total fluxes. The following partitioning of the components is derived from the CarbonTracker analysis: a contribution of about $70 \%$ of the biospheric fluxes, $25 \%$ of fossil fuel, and $5 \%$ of fire emissions. Although fossil fuel emissions typically increase monotonically from year to year for hemispheric means in contrast to the atmospheric $\mathrm{XCO}_{2}$ growth, they contribute perceptibly to the interannual variability of the growth rates in the Northern Hemisphere. This is because fossil fuel emissions slightly decreased by $1.3 \%$ in 2009 as an exception to the rule due to the global economic crisis (Friedlingstein et al., 2010). In the Southern Hemisphere biospheric fluxes are also the largest contributor to the covariation, although the net biospheric sink is considerably smaller than in the Northern Hemisphere and hardly exceeds the fire emissions. Specifically, the contributions amount to $65 \%$ for the biospheric fluxes compared with $35 \%$ for fire emissions, whereas the influence of fossil fuel emissions is negligible in the Southern Hemisphere.

As the biospheric fluxes during the growing season have been identified to predominantly drive the variability of the $\mathrm{XCO}_{2}$ growth rate, the next logical step is to incorporate surface temperature, which influences the warm season 
biosphere. To this end, we use global surface temperature anomalies (relative to the 2000-2010 mean) from the NASA Goddard Institute for Space Studies (Hansen et al., 2010). To analyse the connection of temperature and atmospheric $\mathrm{CO}_{2}$ growth, Fig. 3 also shows the covariation of annual atmospheric growth rate and warm season surface temperature anomaly for the Northern Hemisphere. To focus on the active biosphere, the surface temperature anomalies throughout this manuscript are calculated excluding ocean, snow/ice, and barren or sparsely vegetated regions as provided by the MODIS IGBP Land Cover product (Friedl et al., 2010). Both the SCIAMACHY and CarbonTracker growth rates correlate significantly with the temperature anomaly at the $98 \%$ significance level, exhibiting larger growth rates for warmer years. The corresponding covariation amounts to $1.25 \pm 0.32 \mathrm{ppm} \mathrm{yr}^{-1} \mathrm{~K}^{-1}$ for SCIAMACHY and $1.28 \pm 0.28 \mathrm{ppm} \mathrm{yr}^{-1} \mathrm{~K}^{-1}$ for CarbonTracker, indicating consistently that the efficiency of the terrestrial carbon sink decreases with increasing temperature during the growing season, which is in line with the expected net response of plant metabolism to warming. Using the conversion factor $\gamma=2.128 \mathrm{PgC} \mathrm{ppm}^{-1}$ (Sarmiento et al., 2010), the obtained temperature sensitivity can be rewritten as $2.7 \pm$ $0.7 \mathrm{PgC} \mathrm{yr}^{-1} \mathrm{~K}^{-1}$. Although not directly comparable due to different analysed regions and periods, this estimate is consistent with temperature sensitivities derived from accurate in situ surface measurements (Wang et al., 2013) and lies in the range of results obtained from coupled climate carbon cycle models (Cox et al., 2013).

The relationship is less pronounced in the Southern Hemisphere, as can be seen in Fig. $4\left(0.93 \pm 0.38 \mathrm{ppmyr}^{-1} \mathrm{~K}^{-1}\right.$ for SCIAMACHY and $0.88 \pm 0.19 \mathrm{ppm} \mathrm{yr}^{-1} \mathrm{~K}^{-1}$ for CarbonTracker). This seems to be reasonable because the bulk of the terrestrial carbon sink is located in the Northern Hemisphere. However, the larger relative contribution of fire emissions to the covariation in the Southern Hemisphere (35\% instead of a negligible $5 \%$ ), which might also be correlated with temperature to some extent, complicates the quantitative interpretation of the southern hemispheric covariations. The temperature anomaly correlates significantly with the CarbonTracker growth rate at the $99 \%$ and with the SCIAMACHY growth rate at the $90 \%$ significance level (on the very edge to the $95 \%$ significance level) for the Southern Hemisphere.

\subsection{Seasonal cycle amplitude}

In contrast to the growth rates, the seasonal cycle peakto-peak amplitude differences between SCIAMACHY and CarbonTracker are significant in the Northern Hemisphere $(7.15 \pm 0.22 \mathrm{ppm}$ compared with $6.27 \pm 0.21 \mathrm{ppm})$, whereas they agree within errors in the Southern Hemisphere ( $1.65 \pm 0.23 \mathrm{ppm}$ compared with $1.47 \pm 0.13 \mathrm{ppm})$. Thus, the retrieved SCIAMACHY seasonal cycle amplitudes are on average about $10-15 \%$ larger in both hemispheres. The results for several latitude bands are summarised in Table 1 ,
Table 1. Mean peak-to-peak amplitudes of SCIAMACHY and CarbonTracker $\mathrm{XCO}_{2}$ seasonal cycles for selected latitude bands.

\begin{tabular}{lcc}
\hline Latitude band & \multicolumn{2}{c}{ Seasonal cycle amplitude [ppm] } \\
\cline { 2 - 3 } & SCIA & $\mathrm{CT}$ \\
\hline Global & $3.33 \pm 0.24$ & $2.83 \pm 0.25$ \\
$\mathrm{NH}$ & $7.15 \pm 0.22$ & $6.27 \pm 0.21$ \\
$\mathrm{SH}$ & $1.65 \pm 0.23$ & $1.47 \pm 0.13$ \\
$30-90^{\circ} \mathrm{N}$ & $7.73 \pm 0.31$ & $7.38 \pm 0.28$ \\
$30^{\circ} \mathrm{S}-30^{\circ} \mathrm{N}$ & $1.45 \pm 0.10$ & $1.16 \pm 0.13$ \\
$90-30^{\circ} \mathrm{S}$ & $1.96 \pm 0.37$ & $1.22 \pm 0.27$ \\
\hline
\end{tabular}

showing that the largest relative discrepancy is obtained for the southern temperate zone and that the best agreement is achieved for northern mid- and high latitudes where the satellite seasonal cycle is about 5\% larger compared with CarbonTracker. These seasonal cycle differences are similar to differences found between CarbonTracker and TCCON (Keppel-Aleks et al., 2012; Wunch et al., 2013).

To further analyse the response of the terrestrial carbon sink to changes in temperature, Fig. 5 depicts the covariation of annual seasonal cycle amplitudes and the Northern Hemisphere warm season surface temperature anomaly for the north temperate zone, where most of the biospheric sink is located. Due to the decreased efficiency of the terrestrial carbon sink at high temperatures, one would expect smaller seasonal cycle amplitudes associated with warmer years. The derived consistent covariations of $-1.30 \pm 0.31 \mathrm{ppm} \mathrm{K}^{-1}$ for SCIAMACHY and $-1.06 \pm 0.32 \mathrm{ppm} \mathrm{K}^{-1}$ for CarbonTracker confirm that this is actually the case. This anticorrelated variation of seasonal cycle amplitudes with temperature anomaly during the growing season is detectable at the $98 \%$ significance level. There are no significant correlations and no covariations differing significantly from zero when using the cold season temperature anomaly instead. Together with the finding that the fluxes during the growing season dominate distinctly the variability of the annual fluxes, it can be concluded that the variation of the seasonal cycle amplitudes is essentially driven by the variability of carbon uptake of the ecosystem during the growing season and that the contribution of wintertime respiration is small. In combination with the variability of the atmospheric growth rate described in the previous subsection, this provides a consistent overall picture of the atmosphere-biosphere interaction varying in response to surface temperature changes.

To check the consistency, the analysis above is repeated for another SCIAMACHY data set derived using the Bremen Optimal Estimation DOAS (BESD) algorithm (Reuter et al., 2010, 2011). For details concerning the latest version, BESDv02.00.08, in particular with respect to the applied (post-processing) bias correction, see Reuter et al. (2013). The respective results are shown in Fig. 6. For the comparison with Fig. 5, it has to be noted that the averaging 

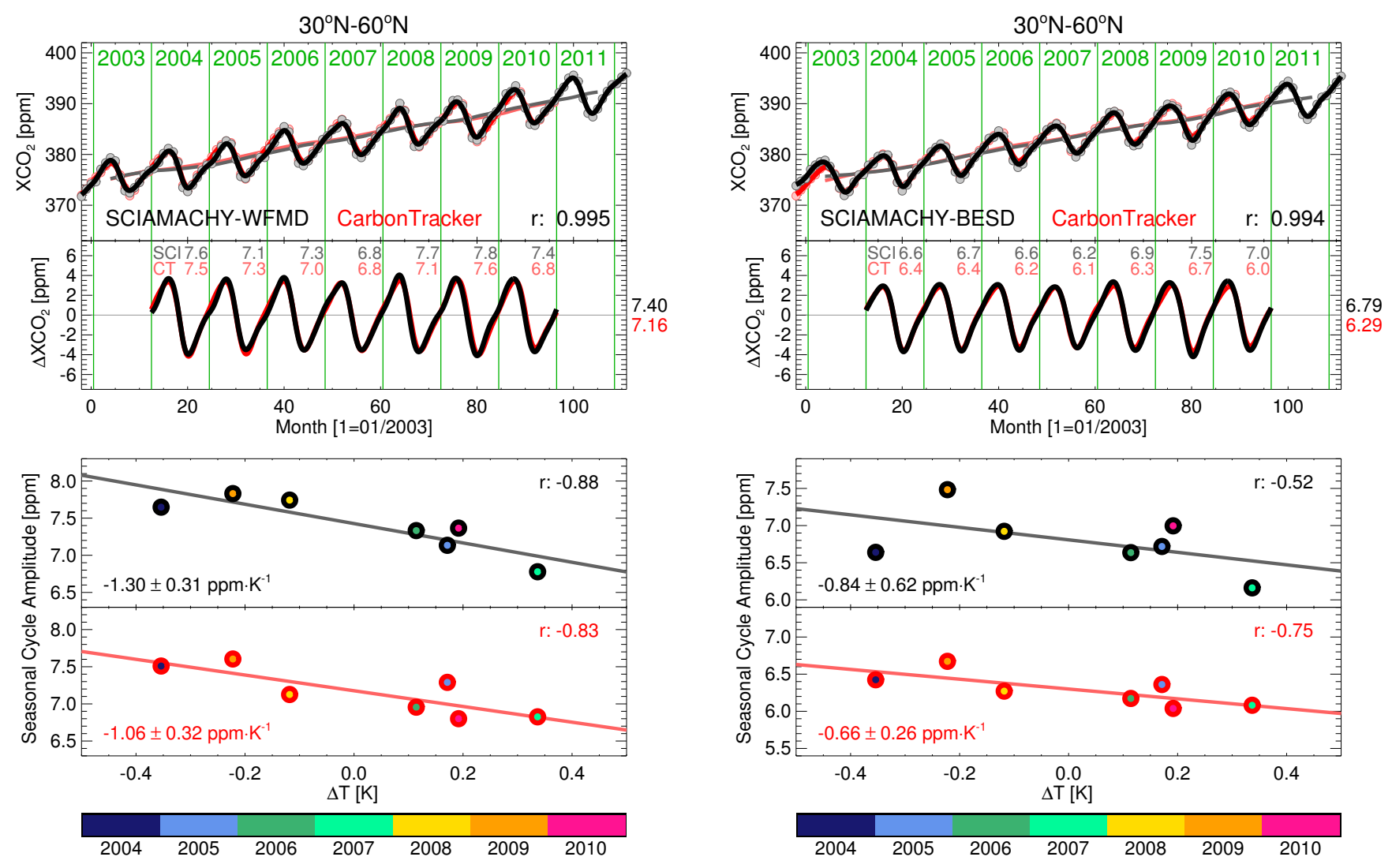

Fig. 5. Comparison of the SCIAMACHY (black) and CarbonTracker (red) $\mathrm{XCO}_{2}$ for the north temperate zone $\left(30-60^{\circ} \mathrm{N}\right)$ based on monthly means. Shown below are the detrended time series obtained by subtracting the deseasonalised trends (pale solid lines). Also noted are annual mean values of the seasonal cycle amplitudes (differences of maxima and minima of detrended seasonal cycle) as well as the mean value of the whole time period on the right-hand side. The bottom panel shows the covariation of annual seasonal cycle amplitudes and the Northern Hemisphere warm season (AprilSeptember) surface temperature anomaly.

kernels of WFMD and BESD, which are also applied to CarbonTracker to take the satellite altitude sensitivities into account, differ quantitatively (although the shapes are similar), with WFMD exhibiting larger sensitivity to $\mathrm{CO}_{2}$ changes at the surface. Hence, the retrieved seasonal cycle amplitudes of BESD are systematically somewhat smaller than for WFMD, but consistently some percents larger than the corresponding CarbonTracker values in both cases. This is also why the derived covariations with temperature anomaly are smaller $\left(-0.84 \pm 0.62 \mathrm{ppm} \mathrm{K}^{-1}\right.$ for SCIAMACHY and $-0.66 \pm 0.26 \mathrm{ppm} \mathrm{K}^{-1}$ for CarbonTracker) compared with Fig. 5, but again quantitatively consistent with each other and not significantly different compared to the previously derived somewhat larger values for WFMD sensitivity. In particular, the CarbonTracker gradients in Figs. 5 and 6 are different, albeit not significantly, due to the different averaging kernels of WFMD and BESD. Apart from this, the interannual

Fig. 6. As Fig. 5 but for the BESD algorithm. The CarbonTracker amplitudes and the corresponding gradient are different from Fig. 5 due to application of different algorithm-specific averaging kernels (see main text for details).

variabilities of the respective CarbonTracker seasonal cycle amplitudes (with WFMD and BESD averaging kernels) are highly correlated $(r=0.97)$ indicating that the different sampling patterns only marginally influence the obtained covariations. Although the observed satellite covariations are about $25 \%$ larger than the modelled ones for both SCIAMACHY algorithms, the satellite and model estimates agree within the error bars, respectively. Overall, we obtain consistent results using two independent retrieval algorithms, corroborating the linear relationship between warm season surface temperature anomaly and seasonal cycle amplitude.

\section{Conclusions}

Significant interannual variability of atmospheric $\mathrm{CO}_{2}$ growth and seasonal cycle strength was observed and ascribed to variations of the terrestrial biosphere, which is currently acting as a net carbon sink. In this context, linear relationships between the sensitivity of annual $\mathrm{CO}_{2}$ growth rates and seasonal cycle amplitudes to growing season surface temperature anomalies were identified using multiyear SCIAMACHY nadir measurements. All derived covariations 
are quantitatively consistent with CarbonTracker assimilations, indicating that the temperature sensitivities of the modelled fluxes are realistic. The obtained correlations are typically detected at the $98 \%$ significance level. Thereby, warmer years can be associated with larger atmospheric growth rates and smaller seasonal cycle amplitudes providing a robust characterisation of the interannual variability of a crucial part of the atmosphere-biosphere interaction. The identified correlations suggest that the efficiency of the terrestrial carbon sink decreases with warming. Under the assumption that the corresponding underlying mechanistic forcing of the current biosphere is not only transitory, this could result in a future sink saturation as a consequence of a positive carbon-climate feedback.

However, the derived decadal-scale temperature response does not necessarily allow reliable longer-term projections of climate-biosphere interactions, because the future biosphere might have different carbon content due to divergent plant populations or thermal adaption. Moreover, climate has several different effects on the biosphere, and a potential feedback and its strength depend on how the individual processes respond and which dominate in different temperature ranges. Due to the obtained simple linear relationship between growing season temperature anomaly and carbon uptake, decreasing NEE with increasing temperature under unstressed conditions, which is dominated by warming-enhanced respiration, is considered to be the prevailing effect of temperature on the biosphere during the analysed time period. In that case, future climate change with an increase in extreme weather conditions, e.g. heat waves or droughts, will have the additional potential to further accelerate the positive feedback mentioned above due to inhibited carbon uptake by vegetation caused by stomatal closure or enzyme denaturation. On the other hand, potential negative feedbacks, like $\mathrm{CO}_{2}$ fertilisation, may counter the proposed positive carbonclimate feedback, at least partially.

The ability to determine characteristics of the terrestrial carbon sink and its potential response to a changing climate from satellite observations is promising and reinforces the beneficial effect of a comprehensive monitoring system comprising accurate in situ and satellite measurements (Ciais et al., 2013), in which remote sensing of column-averaged mole fractions of atmospheric carbon dioxide with global coverage offers complementary information to the very exact and precise but inevitably sparse ground-based measurements. In combination with inverse modelling such a system would deliver improved knowledge of the carbon cycle, which is essential for better prediction of future climate.

Acknowledgements. We thank ESA and DLR for providing us with the SCIAMACHY Level 1 data and the SCIAMACHY calibration team (DLR, SRON, University of Bremen, ESA, and others) for continuously improving the quality of the spectra. CarbonTracker 2011_oi results were provided by NOAA ESRL, Boulder, Colorado, USA from the website at http://carbontracker.noaa.gov/. Sur- face temperature anomalies were obtained from the Goddard Institute for Space Studies via http://data.giss.nasa.gov/gistemp/maps/. TCCON data were obtained from the TCCON Data Archive, operated by the California Institute of Technology from the website at http://tccon.ipac.caltech.edu/.

The research leading to these results has received funding from the ESA project GHG-CCI, the DLR grant SADOS, and from the University and the State of Bremen.

Edited by: B. N. Duncan

\section{References}

Bovensmann, H., Burrows, J. P., Buchwitz, M., Frerick, J., Noël, S., Rozanov, V. V., Chance, K. V., and Goede, A. P. H.: SCIAMACHY - Mission Objectives and Measurement Modes, J. Atmos. Sci., 56, 127-150, doi:10.1175/15200469(1999)056<0127:SMOAMM>2.0.CO;2, 1999.

Braswell, B. H., Schimel, D. S., Linder, E., and Moore, B.: The Response of Global Terrestrial Ecosystems to Interannual Temperature Variability, Science, 278, 870-872, doi:10.1126/science.278.5339.870, 1997.

Buchwitz, M., de Beek, R., Noël, S., Burrows, J. P., Bovensmann, H., Bremer, H., Bergamaschi, P., Körner, S., and Heimann, M.: Carbon monoxide, methane and carbon dioxide columns retrieved from SCIAMACHY by WFM-DOAS: year 2003 initial data set, Atmos. Chem. Phys., 5, 3313-3329, doi:10.5194/acp-53313-2005, 2005.

Burrows, J. P., Hölzle, E., Goede, A. P. H., Visser, H., and Fricke, W.: SCIAMACHY - Scanning Imaging Absorption Spectrometer for Atmospheric Chartography, Acta Astronaut., 35, 445-451, doi:10.1016/0094-5765(94)00278-T, 1995.

Ciais, P., Reichstein, M., Viovy, N., Granier, A., Ogée, J., Allard, V., Aubinet, M., Buchmann, N., Bernhofer, C., Carrara, A., Chevallier, F., De Noblet, N., Friend, A. D., Friedlingstein, P., Grünwald, T., Heinesch, B., Keronen, P., Knohl, A., Krinner, G., Loustau, D., Manca, G., Matteucci, G., Miglietta, F., Ourcival, J. M., Papale, D., Pilegaard, K., Rambal, S., Seufert, G., Soussana, J. F., Sanz, M. J., Schulze, E. D., Vesala, T., and Valentini, R.: Europe-wide reduction in primary productivity caused by the heat and drought in 2003, Nature, 437, 529-533, doi:10.1038/nature03972, 2005.

Ciais, P., Dolman, A. J., Bombelli, A., Duren, R., Peregon, A., Rayner, P. J., Miller, C., Gobron, N., Kinderman, G., Marland, G., Gruber, N., Chevallier, F., Andres, R. J., Balsamo, G., Bopp, L., Bréon, F.-M., Broquet, G., Dargaville, R., Battin, T. J., Borges, A., Bovensmann, H., Buchwitz, M., Butler, J., Canadell, J. G., Cook, R. B., DeFries, R., Engelen, R., Gurney, K. R., Heinze, C., Heimann, M., Held, A., Henry, M., Law, B., Luyssaert, S., Miller, J., Moriyama, T., Moulin, C., Myneni, R. B., Nussli, C., Obersteiner, M., Ojima, D., Pan, Y., Paris, J.-D., Piao, S. L., Poulter, B., Plummer, S., Quegan, S., Raymond, P., Reichstein, M., Rivier, L., Sabine, C., Schimel, D., Tarasova, O., Valentini, R., van der Werf, G., Wickland, D., Williams, M., and Zehner, C.: Current systematic carbon cycle observations and needs for implementing a policy-relevant carbon observing system, Biogeosciences Discuss., 10, 11447 11581, doi:10.5194/bgd-10-11447-2013, 2013. 
Climate Change 2007: The physical science basis, Contribution of working group I to the Fourth Assessment Report of the Intergovernmental Panel on Climate Change (IPCC), edited by: Solomon, S., Qin, D., Manning, M., Chen, Z., Marquis, M., Averyt, K. B., Tignor, M., and Miller, H. L., Cambridge University Press, 2007.

Cox, P. M., Pearson, D., Booth, B. B., Friedlingstein, P., Huntingford, C., Jones, C. D., and Luke, C. M.: Sensitivity of tropical carbon to climate change constrained by carbon dioxide variability, Nature, 494, 341-344, doi:10.1038/nature11882, 2013.

Friedl, M. A., Strahler, A. H., and Hodges, J.: ISLSCP II MODIS (Collection 4) IGBP Land Cover, 2000-2001, in: ISLSCP Initiative II Collection. Data set, edited by: Hall, F. G., Collatz, G., Meeson, B., Los, S., Brown de Colstoun, E., and Landis, D., available online at: http://daac.ornl.gov/ from Oak Ridge National Laboratory Distributed Active Archive Center, Oak Ridge, Tennessee, USA, doi:10.3334/ORNLDAAC/968, 2010.

Friedlingstein, P., Houghton, R. A., Marland, G., Hackler, J., Boden, T. A., Conway, T. J., Canadell, J. G., Raupach, M. R., Ciais, P., and Le Quéré, C.: Update on $\mathrm{CO}_{2}$ emissions, Nat. Geosci., 3, 811-812, doi:10.1038/ngeo1022, 2010.

Guerlet, S., Butz, A., Schepers, D., Basu, S., Hasekamp, O. P., Kuze, A., Yokota, T., Blavier, J.-F., Deutscher, N. M., Griffith, D. W. T., Hase, F., Kyro, E., Morino, I., Sherlock, V., Sussmann, R., Galli, A., and Aben, I.: Impact of aerosol and thin cirrus on retrieving and validating $\mathrm{XCO}_{2}$ from GOSAT shortwave infrared measurements, J. Geophys. Res., 118, 4887-4905, doi:10.1002/jgrd.50332, 2013a.

Guerlet, S., Basu, S., Butz, A., Krol, M., Hahne, P., Houweling, S., Hasekamp, O. P., and Aben, I.: Reduced carbon uptake during the 2010 Northern Hemisphere summer from GOSAT, Geophys. Res. Lett., 40, 2378-2383, doi:10.1002/grl.50402, 2013b.

Hansen, J., Ruedy, R., Sato, M., and Lo, K.: Global surface temperature change, Rev. Geophys., 48, RG4004, doi:10.1029/2010RG000345, 2010.

Heymann, J., Bovensmann, H., Buchwitz, M., Burrows, J. P., Deutscher, N. M., Notholt, J., Rettinger, M., Reuter, M., Schneising, O., Sussmann, R., and Warneke, T.: SCIAMACHY WFM-DOAS $X \mathrm{CO}_{2}$ : reduction of scattering related errors, Atmos. Meas. Tech., 5, 2375-2390, doi:10.5194/amt-5-2375-2012, 2012.

Houghton, R. A.: Interannual variability in the global carbon cycle, J. Geophys. Res., 105, 20121-20130, doi:10.1029/2000JD900041, 2000.

Keppel-Aleks, G., Wennberg, P. O., Washenfelder, R. A., Wunch, D., Schneider, T., Toon, G. C., Andres, R. J., Blavier, J.-F., Connor, B., Davis, K. J., Desai, A. R., Messerschmidt, J., Notholt, J., Roehl, C. M., Sherlock, V., Stephens, B. B., Vay, S. A., and Wofsy, S. C.: The imprint of surface fluxes and transport on variations in total column carbon dioxide, Biogeosciences, 9, 875891, doi:10.5194/bg-9-875-2012, 2012.

Kuze, A., Suto, H., Nakajima, M., and Hamasaki, T.: Thermal and near infrared sensor for carbon observation Fouriertransform spectrometer on the Greenhouse Gases Observing Satellite for greenhouse gases monitoring, Appl. Opt., 48, 67166733, doi:10.1364/AO.48.006716, 2009.

Le Quéré, C., Andres, R. J., Boden, T., Conway, T., Houghton, R. A., House, J. I., Marland, G., Peters, G. P., van der Werf, G. R., Ahlström, A., Andrew, R. M., Bopp, L., Canadell, J. G., Ciais, P., Doney, S. C., Enright, C., Friedlingstein, P., Huntingford, C.,
Jain, A. K., Jourdain, C., Kato, E., Keeling, R. F., Klein Goldewijk, K., Levis, S., Levy, P., Lomas, M., Poulter, B., Raupach, M. R., Schwinger, J., Sitch, S., Stocker, B. D., Viovy, N., Zaehle, S., and Zeng, N.: The global carbon budget 1959-2011, Earth Syst. Sci. Data, 5, 165-185, doi:10.5194/essd-5-165-2013, 2013.

Myneni, R. B., Los, S. O., and Asrar, G.: Potential gross primary productivity of terrestrial vegetation from 1982-1990, Geophys. Res. Lett., 22, 2617-2620, doi:10.1029/95GL02562, 1995.

Peters, W., Jacobson, A. R., Sweeney, C., Andrews, A. E., Conway, T. J., Masarie, K., Miller, J. B., Bruhwiler, L. M. P., Pétron, G., Hirsch, A. I., Worthy, D. E. J., van der Werf, G. R., Randerson, J. T., Wennberg, P. O., Krol, M. C., and Tans, P. P.: An atmospheric perspective on North American carbon dioxide exchange: CarbonTracker, Proc. Natl. Acad. Sci. USA, 104, 18925-18930, doi:10.1073/pnas.0708986104, 2007.

Reuter, M., Buchwitz, M., Schneising, O., Heymann, J., Bovensmann, H., and Burrows, J. P.: A method for improved SCIAMACHY $\mathrm{CO}_{2}$ retrieval in the presence of optically thin clouds, Atmos. Meas. Tech., 3, 209-232, doi:10.5194/amt-3-209-2010, 2010.

Reuter, M., Bovensmann, H., Buchwitz, M., Burrows, J. P., Connor, B. J., Deutscher, N. M., Griffith, D. W. T., Heymann, J., Keppel-Aleks, G., Messerschmidt, J., Notholt, J., Petri, C., Robinson, J., Schneising, O., Sherlock, V., Velazco, V., Warneke, T., Wennberg, P. O., and Wunch, D.: Retrieval of atmospheric $\mathrm{CO}_{2}$ with enhanced accuracy and precision from SCIAMACHY: Validation with FTS measurements and comparison with model results, J. Geophys. Res., 116, D04301, doi:10.1029/2010JD015047, 2011.

Reuter, M., Bovensmann, H., Buchwitz, M., Burrows, J. P., Heymann, J., Hilker, M., and Schneising, O.: Algorithm Theoretical Basis Document Version 2 (ATBDv2) - The Bremen Optimal Estimation DOAS (BESD) algorithm for the retrieval of $\mathrm{XCO}_{2}$, in preparation, 2013.

Sarmiento, J. L., Gloor, M., Gruber, N., Beaulieu, C., Jacobson, A. R., Mikaloff Fletcher, S. E., Pacala, S., and Rodgers, K.: Trends and regional distributions of land and ocean carbon sinks, Biogeosciences, 7, 2351-2367, doi:10.5194/bg-7-2351-2010, 2010.

Schneising, O., Buchwitz, M., Burrows, J. P., Bovensmann, H., Reuter, M., Notholt, J., Macatangay, R., and Warneke, T.: Three years of greenhouse gas column-averaged dry air mole fractions retrieved from satellite - Part 1: Carbon dioxide, Atmos. Chem. Phys., 8, 3827-3853, doi:10.5194/acp-8-3827-2008, 2008.

Schneising, O., Buchwitz, M., Reuter, M., Heymann, J., Bovensmann, H., and Burrows, J. P.: Long-term analysis of carbon dioxide and methane column-averaged mole fractions retrieved from SCIAMACHY, Atmos. Chem. Phys., 11, 2863 2880, doi:10.5194/acp-11-2863-2011, 2011.

Schneising, O., Bergamaschi, P., Bovensmann, H., Buchwitz, M., Burrows, J. P., Deutscher, N. M., Griffith, D. W. T., Heymann, J., Macatangay, R., Messerschmidt, J., Notholt, J., Rettinger, M., Reuter, M., Sussmann, R., Velazco, V. A., Warneke, T., Wennberg, P. O., and Wunch, D.: Atmospheric greenhouse gases retrieved from SCIAMACHY: comparison to ground-based FTS measurements and model results, Atmos. Chem. Phys., 12, 1527-1540, doi:10.5194/acp-12-1527-2012, 2012.

Schneising, O., Heymann, J., Buchwitz, M., Reuter, M., Bovensmann, H., and Burrows, J. P.: Anthropogenic carbon dioxide source areas observed from space: assessment of regional 
enhancements and trends, Atmos. Chem. Phys., 13, 2445-2454, doi:10.5194/acp-13-2445-2013, 2013.

Wang, W., Ciais, P., Nemani, R. R., Canadell, J. G., Piao, S., Sitch, S., White, M. A., Hashimoto, H., Milesi, C., and Myneni, R. B.: Variations in atmospheric $\mathrm{CO}_{2}$ growth rates coupled with tropical temperature, Proc. Natl. Acad. Sci. USA, 110, 13061-13066, doi:10.1073/pnas.1219683110, 2013.

Woodwell, G. M., Mackenzie, F. T., Houghton, R. A., Apps, M., Gorham, E., and Davidson, E.: Biotic feedbacks in the warming of the Earth, Clim. Change, 40, 495-518, doi:10.1023/A:1005345429236, 1998.

Wunch, D., Toon, G. C., Blavier, J.-F. L., Washenfelder, R. A., Notholt, J., Connor, B. J., Griffith, D. W. T., Sherlock, V., and Wennberg, P. O.: The Total Carbon Column Observing Network, Phil. Trans. R. Soc. A, 369, 2087-2112, doi:10.1098/rsta.2010.0240, 2011a.

Wunch, D., Wennberg, P. O., Toon, G. C., Connor, B. J., Fisher, B., Osterman, G. B., Frankenberg, C., Mandrake, L., O’Dell, C., Ahonen, P., Biraud, S. C., Castano, R., Cressie, N., Crisp, D., Deutscher, N. M., Eldering, A., Fisher, M. L., Griffith, D. W. T., Gunson, M., Heikkinen, P., Keppel-Aleks, G., Kyrö, E., Lindenmaier, R., Macatangay, R., Mendonca, J., Messerschmidt, J., Miller, C. E., Morino, I., Notholt, J., Oyafuso, F. A., Rettinger, M., Robinson, J., Roehl, C. M., Salawitch, R. J., Sherlock, V., Strong, K., Sussmann, R., Tanaka, T., Thompson, D. R., Uchino, O., Warneke, T., and Wofsy, S. C.: A method for evaluating bias in global measurements of $\mathrm{CO}_{2}$ total columns from space, Atmos. Chem. Phys., 11, 12317-12337, doi:10.5194/acp11-12317-2011, 2011 b.
Wunch, D., Wennberg, P. O., Messerschmidt, J., Parazoo, N. C., Toon, G. C., Deutscher, N. M., Keppel-Aleks, G., Roehl, C. M., Randerson, J. T., Warneke, T., and Notholt, J.: The covariation of Northern Hemisphere summertime $\mathrm{CO}_{2}$ with surface temperature in boreal regions, Atmos. Chem. Phys., 13, 9447-9459, doi:10.5194/acp-13-9447-2013, 2013. 